\title{
Comparison between Carotid Intima-Media Thickness and Coronary Artery Calcification in the Prediction of Atherosclerosis in Diabetic Patients
}

\author{
Rusli Muljadi ${ }^{1, *}$, Bachtiar Murtala ${ }^{2},{\text { Peter } \mathrm{Kabo}^{3} \text {, Budhianto Suhadi }}^{4}$ \\ ${ }^{1}$ Postgraduate Program in Biomedics, Hasanuddin University, Jl. Perintis Kemerdekaan Km.10, Makassar, Indonesia \\ ${ }^{2}$ Department of Radiology, Faculty of Medicine, Hasanuddin University, Jl. Perintis Kemerdekaan Km.10, Makassar, Indonesia \\ ${ }^{3}$ Department of Cardiology, Faculty of Medicine, Hasanuddin University, Jl. Perintis Kemerdekaan Km.10, Makassar, Indonesia \\ ${ }^{4}$ Department of Clinical Pathology, Faculty of Medicine, Pelita Harapan University, Jl. Boulevard Jend. Sudirman Lippo Karawaci, Tangerang, Indonesia \\ *Corresponding author. E-mail: ruslimuljadi@yahoo.com
}

\section{Abstract}

B ACKGROUND: Cardiovascular disease is one of the atherosclerosis etiologies that can lead to death. Diabetes mellitus increases the risk of atherosclerosis. Screening tool is very beneficial for detecting atherosclerotic plaque, especially in subclinical atherosclerotic cases. Carotid intima-media thickness (CIMT) and coronary artery calcification score (CACS) are two kinds of tools that are widely used, and each of these tools has its own superiority. This study was aimed to investigate the sensitivity and specificity of both of these tools as screening tools.

METHODS: The study was conducted with a cross sectional design involving 43 diabetic and 68 non-diabetic male subjects aged above 45 years old. All subjects fulfilled inclusion criteria. Carotid artery ultrasonography and CACS measurement were performed.

RESULTS: Fischer exact test was used to show a significant correlation between CIMT and CACS $(p<0.05)$. Diagnostic test was used to assess the sensitivity of CIMT toward CACS in above 75 percentile. The left common carotid artery (LCCA) showed the highest sensitivity either in diabetic (76.4\%) or non-diabetic male subjects $(90 \%)$.

CONCLUSION: CIMT has the same sensitivity with CACS. CIMT can be used as the preferred screening tool for high risk patients and as a substitution tool to CACS for low risk patients in subclinical atherosclerosis detection.

\section{Abstrak}

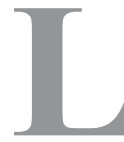

ATAR BELAKANG: Penyakit kardiovaskular adalah salah satu etiologi aterosklerosis yang dapat menyebabkan kematian. Diabetes melitus meningkatkan risiko ateosklerosis. Alat skrining sangat diperlukan untuk mendeteksi plak aterosklerosis, khususnya pada kasus aterosklerosis subklinikal. Carotid intima-media thickness (CIMT) dan coronary artery calcification score (CACS) adalah dua jenis alat yang banyak digunakan dan masing-masing memiliki kelebihan. Penelitian ini bertujuan menyelidiki sensitivitas dan spesifisitas dari kedua alat skrining tersebut.

METODE: Penelitian dilakukan dengan desain potong lintang yang melibatkan subyek laki-laki, 43 diabetes dan 68 non-diabetes, yang berumur di atas 45 tahun. Semua subyek memenuhi kriteria inklusi. Carotid artery ultrasonography dan pengukuran CACS dilakukan.

HASIL: Fischer exact test digunakan untuk memperlihatkan korelasi bermakna antara CIMT dan CACS $(p<0,05)$. Tes diagnostik digunakan utk menilai sensitivitas CIMT terhadap CACS di atas 75 persen. Left common carotid artery (LCCA) memperlihatkan sensitivitas tertinggi pada subyek laki-laki diabetes $(76,4 \%)$ atau non-diabetes $(90 \%)$.

KESIMPULAN: CIMT memiliki sensitivitas yang sama dengan CACS. CIMT dapat digunakan sebagai pilihan alat skrining untuk pasien risiko tinggi dan sebagai alat pengganti untuk CACS untuk pasien risiko rendah pada deteksi aterosklerosis subklinis. 
KEYWORDS: atherosclerosis, diabetes mellitus, carotid intima-media thickness, coronary artery calcification score
KATA KUNCI: aterosklerosis, diabetes melitus, carotid intima-media thickness, coronary artery calcification score

Indones Biomed J. 2014; 6(1): 45-50

\section{Introduction}

Cardiovascular disease (CVD) is the number one cause of mortality worldwide. Identifying the "vulnerable patient" is clinically important because of the fact that initial manifestation of CVD causes sudden death in approximately $20 \%$ of patients.(1) Diabetes mellitus has been known as the risk factor for coronary heart disease. The incidence has increased two until four folds compared with patients without diabetes mellitus.(2) Together with hypertension, smoking, dyslipidemia, age and sex are the other contributing factors that ameliorate coronary heart disease. $(3,4)$ These findings will increase the mortality risk and give several implications of insulin resistance, visceral adiposity and excess inflammation that finally underlie the pathophysiology of atherosclerosis.(5-7)

There are many similarities between atherosclerotic plaque in carotid and that in the coronary artery. Intimal thickening is the first manifestation of atherosclerosis. Deep portion of the intima contains rich lipid which is subsequently accompanied by loss of smooth muscle and calcification. (8) Necrotic core will be formed after this process. A study shows necrotic core is the predictor for plaque rupture and cerebrovascular event. $(9,10)$ Initial screening is absolutely needed to prevent further progress of atherosclerotic plaque.

Carotid intima-media thickness (CIMT) and coronary artery calcification score (CACS) are some of the noninvasive diagnostic tools that have been widely used. These modalities can predict atherosclerosis plaque and grade its vascular event. $(1,11,12)$ Quite often equipment for CACS measurement is not available in some centers in Indonesia. CIMT is more available but the technique needs the experience of an operator.

CACS is more beneficial in advanced diseases. Diabetic patients associate with tunica media calcification, also referred to as Monckeberg's sclerosis, beside intimal atherosclerosis calcification. Because medial and intimal layers are in close proximity, noninvasive measures of vascular calcification (particularly CACS) generally do not distinguish them.(13)

The purpose of this study is to determine the ability of CIMT to substitute CACS to detect subclinical atherosclerosis especially in diabetic patients.

\section{Methods}

This study involved diabetic male patients with age above 45 years old. All cardiovascular risk factors (dyslipidemia, hypertension and obesity) were examined. Non diabetic male subjects were taken as control. CACS and CIMT were performed in all subjects. Patients were excluded from the study if they ever had percutaneous trans-coronary intervention (PTCI) or coronary bypass surgery and anticoagulant administration.

\section{CACS}

Coronary artery calcium evaluation was performed using Dual Source computerised tomography (CT) scan (Siemens, Erlangen, Germany). Data acquisition study was made using electrocardiogram-gated scan with a 3-mm slice thickness from the level of the carina through the bottom of the heart. Coronary calcium measurement were performed with an automated program based on the Agatston method to compute the CACS.(14)

CACS measurements were classified into percentiles based on Raggi criteria.(15) CACS was defined as score below the $25^{\text {th }}$ percentile, between $25^{\text {th }}$ and $50^{\text {th }}$ percentile, between $25^{\text {th }}$ and $75^{\text {th }}$ percentile and the high risk (abnormal) as a score above $75^{\text {th }}$ percentile.

\section{CIMT}

The carotid arteries were imaged with Doppler ultrasound (Vivid 5, General Electric, Buckinghamshire, UK) with an 7.5 to $10 \mathrm{MHz}$ linear-array transducer. The axial resolution was set between 100 and $200 \mu \mathrm{M}$. At depth $30-40 \mathrm{~mm}$ was used. The common carotid was examined at a point $2 \mathrm{~cm}$ proximal to plaque free artery bifurcation with different angle. The average and highest scores were taken.

Measurement of CIMT was performed in common carotid arteries bilaterally and the regions examined were right common carotid artery (RCCA) and left common carotid artery (LCCA). The averages (AV) and the measurements were classified in $\mathrm{AV}$ and maximum for RCCA (Max RCCA) and LCCA (Max LCCA).

Values of CIMT were classified into percentiles based on the multi-ethnic study of atherosclerosis (MESA) criteria (age, sex and race (Chinese was applied).(16) CIMT was 
defined as score below the $25^{\text {th }}$ percentile, between $25^{\text {th }}$ and $75^{\text {th }}$ percentile, and above $75^{\text {th }}$ percentile. The high risk (abnormal) is the score above $75^{\text {th }}$ percentile.

\section{Statistical analysis}

Data were presented as mean $\pm \mathrm{SD}$. By using the Spearman correlation test, we calculated correlation between CACS and CIMT. Then a Fischer exact test was used to measure the association between CACS and CIMT in percentile results with statistical significance if $p$ was below 0.05 . Diagnostic test was used to determine the sensitivity of CIMT toward CACS in percentile above $75^{\text {th }}$.

\section{Results}

\section{Baseline Characteristics}

A total of 111 patients were recruited in the study, of whom 43 were diabetic and 68 were non-diabetic male subjects as the control. All the subjects fulfilled the inclusion and exclusion criteria. The mean $\pm \mathrm{SD}$ of age was $55.82 \pm 7.51$ years. The vascular risk was calculated: smoking (20\%), hypertension (55\%) and dyslipidemia (41\%). The CACS mean \pm SD was $265.24 \pm 451.78$.

Table 1. The CIMT taken in average and maximal scores.

\begin{tabular}{ccc}
\hline Variable & Mean \pm SD & Min/Max \\
\hline RCCA & $0.87 \pm 0.29$ & $0.4 / 2.45$ \\
LCCA & $0.92 \pm 0.28$ & $0.45 / 2.05$ \\
AV & $0.92 \pm 0.25$ & $0.5 / 2.1$ \\
Max RCCA & $0.94 \pm 0.34$ & $0.4 / 2.9$ \\
Max LCCA & $0.98 \pm 0.33$ & $0.5 / 2.5$ \\
\hline
\end{tabular}

RCCA: right common carotid artery; LCCA: left common carotid artery; AV: average score from RCCA and LCCA; Max RCCA: maximal right common carotid artery; Max LCCA: maximal left common carotid artery.

\section{CIMT Results}

The average and maximum scores were taken. The mean \pm SD, minimal and maximal scores were tabulated (Table 1). The relationship between CACS and CIMT in diabetic and non diabetic subjects was analysed. The correlation showed a significant association of RCCA, LCCA, Max RCCA, Max LCCA, and AV with calcium score $(\mathrm{p}<0.05)$.

After we categorized the results into percentile, most subjects were in percentile $>75 \%$ group in CIMT. This showed all subjects in this research were categorized in high risk by CIMT. As shown in Table 3, there was a significant correlation between CIMT and CACS in percentile, as proven by $p$ value $<0.05$.

CACS was classified based on Raggi criteria. CIMT was classified based on MESA criteria (age, sex and race (Chinese was applied) had been adjusted. $p$ value shows the significant correlation between CIMT and CACS. The diagnostic test used to see the sensitivity of CIMT as a substitution tool of CACS.

Table 3. Results of measurement of CACS and CIMT based on percentile.

\begin{tabular}{ccccc}
\hline \multirow{2}{*}{ Variable } & \multicolumn{3}{c}{$\mathbf{N}(\mathbf{\%})$} & \multirow{2}{*}{$\boldsymbol{p}$} \\
\cline { 2 - 4 } & $\mathbf{2 5 \%}$ & $\mathbf{2 5 - 7 5 \%}$ & $\mathbf{7 5 \%}$ & \\
\hline Ca Score & $7(6.31)$ & $66(59.64)$ & $38(34.23)$ \\
RCCA & $10(9.01)$ & $37(33.33)$ & $64(57.66)$ & 0.01 \\
LCCA & $5(4.50)$ & $27(24.32)$ & $79(71.17)$ & 0.019 \\
AV & $10(9.01)$ & $35(31.53)$ & $66(59.46)$ & 0.053 \\
Max RCCA & $13(11.71)$ & $45(40.54)$ & $53(47.75)$ & 0.007 \\
Max LCCA & $7(6.31)$ & $47(42.34)$ & $57(51.35)$ & 0.001 \\
\hline
\end{tabular}

Ca Score: calcium score

Table 2. The Correlation between CACS and CIMT among diabetic and non diabetic subjects.

\begin{tabular}{ccccccc}
\hline \multirow{2}{*}{ Variable } & \multicolumn{2}{c}{ Total } & \multicolumn{2}{c}{ Non Diabetes } & \multicolumn{2}{c}{ Diabetes } \\
\cline { 2 - 7 } & $\mathbf{r}$ & $\boldsymbol{p}$ & $\mathbf{r}$ & $\boldsymbol{p}$ & $\mathbf{r}$ & $\boldsymbol{p}$ \\
\hline RCCA & 0.2505 & 0.008 & 0.2976 & 0.0137 & 0.2191 & 0.158 \\
LCCA & 0.2724 & 0.0038 & 0.2948 & 0.0147 & 0.2434 & 0.1158 \\
Max RCCA & 0.2035 & 0.0321 & 0.1893 & 0.1221 & 0.2424 & 0.1174 \\
Max LCCA & 0.3524 & 0.0001 & 0.316 & 0.0087 & 0.4002 & 0.0078 \\
AV & 0.2578 & 0.0063 & 0.2691 & 0.0265 & 0.2621 & 0.0895 \\
\hline
\end{tabular}


Table 4. The sensitivity and specificity of CIMT toward CACS in all subjects.

\begin{tabular}{ccccc}
\hline Variable & Sensitivity (\%) & Specificity (\%) & PPV (\%) & NPV (\%) \\
\hline Max RCCA & 52.6 & 54.8 & 37.7 & 69 \\
RCCA & 68.4 & 43.9 & 35.9 & 74.4 \\
Max LCCA & 73,7 & 60.3 & 49.1 & 81.5 \\
LCCA & 84.2 & 35.6 & 40.1 & 81.3 \\
AV & 73.7 & 47.9 & 42.4 & 77.8 \\
\hline
\end{tabular}

Table 5. The sensitivity and specificity of CIMT toward CACS in non DM subjects.

\begin{tabular}{ccccc}
\hline Variable & Sensitivity (\%) & Specificity (\%) & PPV (\%) & NPV (\%) \\
\hline Max RCCA & 61.9 & 51 & 36 & 75 \\
RCCA & 85.7 & 42.5 & 40 & 87 \\
Max LCCA & 76.2 & 59.6 & 43,2 & 84.8 \\
LCCA & 90 & 38.3 & 39.6 & 90 \\
AV & 85.7 & 38.3 & 38.3 & 85.7 \\
\hline
\end{tabular}

Table 6. The sensitivity and specificity of CIMT toward CACS in DM subjects.

\begin{tabular}{ccccc}
\hline Variable & Sensitivity (\%) & Specificity (\%) & PPV (\%) & NPV (\%) \\
\hline Max RCCA & 41.1 & 61.5 & 41.1 & 61.5 \\
RCCA & 47 & 57.7 & 47 & 62.5 \\
Max LCCA & 41.1 & 61.5 & 41.1 & 76.5 \\
LCCA & 76.4 & 30.8 & 41.9 & 66.7 \\
AV & 58.8 & 65.4 & 52.6 & 70.8 \\
\hline
\end{tabular}

\section{Discussion}

The main purpose of this study is to assess the sensitivity of CIMT as a substitution tool toward CACS. CIMT is easy to measure as the instrument is available in most locations in Indonesia. This study has shown there is a significant of correlation between CIMT and CACS. Atherosclerosis causes inflammation of blood vessels. Atherosclerosis itself rarely gives symptomatic presentations before 45 years of age in men or 55 years in women.

After we categorized the results into percentile, most subjects were in percentile $>75 \%$ group in CIMT. This showed all subjects in this research were categorized in high risk by CIMT. But patients with CACS percentile $>75^{\text {th }}$ were less than in CIMT percentile $>75^{\text {th }}$. The process starts from the endothelial lining cells and next to the medial muscular layers. Atherosclerosis causes plaque that consists of fibrous cap and necrotic core. The thickness of this plaque can be measured by B mode ultrasound. Atherosclerosis may lead to arterial calcification. Arterial calcification can arise in the initial or late process of atherosclerosis. The zero score of CACS doesn't mean there is no atherosclerosis process, because not all plaques undergo calcification.

Compared with the non diabetic patients, CIMT in diabetic patients had lesser correlation to CACS in percentile. As we know, diabetic patients tend to have more susceptibility to formation of atherosclerosis. Hyperglicemia is the inducer of several inflammation substances like tumor necrosis factor alpha (TNF- $\alpha$ ), interleukin 1 beta (IL-1 $\beta$ ), IL-6 and adhesion molecules. All these circumstances will end up to atherosclerotic plaque. The other things that can accelerate the formation of plaque, including genetic polymorphism, family history, blood cholesterols, smoking and body weight, must be evaluated. So diabetes mellitus may not be the sole factor that can contribute to atherosclerotic plaque.

This study has proven that CIMT was quite sensitive. The highest sensitivity score was seen at LCCA. CIMT can be used as an alternative in the settings where CT scan is not available, so it is of great usefulness for Indonesia. The radiation exposure and the expensive cost cause 
the usage limitation of CT scan for CACS measurement. Both the lower cost and negligible radiation exposure of CIMT measurement make its own superiority to the other measurement techniques, but its application requires mastery of the skill in imaging the intima-medial thickness.

The goal of clinical medicine should be not only to treat but also to prevent disease. It is best to determine which patients may benefit from more aggressive CVD prevention strategies before the occurrence of an adverse atherosclerotic event. Whether screening for subclinical atherosclerosis decreases the incidence of future cardiovascular events has not yet been determined, but clinical guidelines recommend more aggressive preventive interventions for high risk patients. $(1,2)$

CIMT demonstrated high sensitivity, low specificity, low positive predictive value and high negative predictive value. The highest sensitivity of CIMT was LCCA. High sensitivity with low positive predictive value was seen because vascular calcification (CACS) is a late process of atherosclerosis. It is consistent to the study by Lester et al., that CIMT is a more sensitive test than CACS for the detection of subclinical atherosclerosis.(1)

In non diabetic patients, the highest sensitivity with high negative predictive value was shown by RCCA, LCCA and the average. The result recommends use of them, on the condition if we have patients with abnormal CIMT (percentile above $75^{\text {th }}$ ), we must confirm with CACS. But if we have patients with normal CIMT (below $75^{\text {th }}$ percentile), we do not need CACS for further examination.

In diabetic patients, the highest sensitivity with high negative predictive value was shown by LCCA only. The result recommends use of LCCA in diabetic patients. Similarly as with non diabetic patients, if we manage patients with abnormal CIMT (percentile above $75^{\text {th }}$ ), we must confirm with CACS, but if we have patients with normal CIMT (below $75^{\text {th }}$ percentile), we do not need CACS for further examination.

Compared with non diabetic patients, CIMT of diabetic patients has higher positive predictive value. There are four types of vascular calcification that have been identified with at least some distinct properties: intimal atherosclerotic plaque calcification, tunica media calcification, cardiac valve calcification, and vascular calciphylaxis. Tunica media calcification, also referred to as Monckeberg's sclerosis, is associated with aging, diabetes, and chronic kidney disease.(16) Anatomically, it may be intimal atherosclerotic calcification, which occurs in a patchy pattern, or it may be arterial medial calcification, which is more diffuse and independent of atherosclerosis; in the arteriolar vessels, it is known as calcific uremic arteriolopathy or, previously, calciphylaxis. Several boneassociated protein-like osteopontin, bone sialoprotein and alkaline phosphatase are responsible for the calcification process. Because medial and intimal layers are in close proximity, noninvasive measures of vascular calcification generally do not distinguish them.(17)

Consistent to the vascular calcification theory, diabetic patients will have vascular calcification more often than non diabetic patients due to tunica media calcification (Monckeberg's sclerosis), besides intimal atherosclerosis calcification.

\section{Conclusion}

CIMT has high sensitivity and high negative predictive value, particularly in non diabetic patients. In diabetic patients, the sensitivity of CIMT is superior than in non diabetic patients The best CIMT is LCCA, proven to have good sensitivity in non diabetic or diabetic patients. CIMT can be used as the preferred screening tools for high risk patients and as a substitution tool to CACS for low risk patients in subclinical atherosclerosis detection.

\section{References}

1. Lester SJ, Eleid MF, Khandheria BK, Hurst RT. Carotid intimamedia thickness and coronary artery calcium score as indications of subclinical atherosclerosis. Mayo Clin Proc. 2009; 84: 229-33.

2. Kannel WB, McGee DL. Diabetes and cardiovascular disease. The Framingham study. JAMA. 1979; 241: 2035-8.

3. Haffner SM, Lehto S, Ronnemaa T, Pyorala K, Laakso M. Mortality from coronary heart disease in subjects with type 2 diabetes and in nondiabetic subjects with and without prior myocardial infarction. N Engl J Med. 1998; 339: 229-34.

4. Gupta R, Joshi P, Mohan V, Reddy KS, Yusuf S. Epidemiology and causation of coronary heart disease and stroke in India. Heart. 2008; 94: 16-26.

5. Plutzky J, Viberti G, Haffner S. Atherosclerosis in type 2 diabetes mellitus and insulin resistance: mechanistic links and therapeutic targets. J Diabetes Complications. 2002; 16: 401-15.

6. Haffner SM. Abdominal adiposity and cardiometabolic risk: do we have all the answers? Am J Med. 2007; 120(9 Suppl 1): S10-6.

7. Barnett $\mathrm{AH}$. The importance of treating cardiometabolic risk factors in patients with type 2 diabetes. Diab Vasc Dis Res. 2008; 5: 9-14.

8. Virmani R, Kolodgie FD, Burke AP, Farb A, Schwartz SM. Lessons from sudden coronary death: a comprehensive morphological classification scheme for atherosclerotic lesions. Arterioscler Thromb Vasc Biol. 2000; 20: 1262-75.

9. Takaya N, Yuan C, Chu B, Saam T, Underhill H, Cai J, et al. Association between carotid plaque characteristics and subsequent ischemic cerebrovascular events: a prospective assessment with MRI-initial results. Stroke. 2006; 37: 818-23. 
10. Garcia-Garcia HM, Goedhart D, Serruys PW. Relation of plaque size to necrotic core in the three major coronary arteries in patients with acute coronary syndrome as determined by intravascular ultrasonic imaging radiofrequency. Am J Cardiol. 2007; 99: 790-2.

11. Ali YS, Rembold KE, Weaver B, Wills MB, Tatar S, Ayers CR, et al. Prediction of major adverse cardiovascular events by agenormalized carotid intimal medial thickness. Atherosclerosis. 2006; 187: 186-90.

12. Budoff MJ, Shaw LJ, Liu ST, Weinstein SR, Mosler TP, Tseng PH, et al. Long-term prognosis associated with coronary calcification: observations from a registry of 25,253 patients. J Am Coll Cardiol. 2007; 49: 1860-70.

13. Folsom AR, Kronmal RA, Detrano RC, O'Leary DH, Bild DE, Bluemke DA, et al. Coronary artery calcification compared with carotid intima-media thickness in the prediction of cardiovascular disease incidence: the Multi-Ethnic Study of Atherosclerosis (MESA). Arch Intern Med. 2008; 168: 1333-9.

14. Agatston AS, Janowitz WR, Hildner FJ, Zusmer NR, Viamonte M Jr, Detrano R. Quantification of coronary artery calcium using ultrafast computed tomography. J Am Coll Cardiol. 1990; 15: 827-832.

15. Raggi P, Callister TQ, Cooil B, He ZX, Lippolis NJ, Russo DJ, et al. Identification of Patients at Increased Risk of First Unheralded Acute Myocardial Infarction by Electron-Beam Computed Tomography . Circulation. 2000; 101: 850-5.

16. Stein JH, Korcarz CE, Hurst RT, Lonn E, Kendall CB, Mohler ER, et $a l$. Use of carotid ultrasound to identify subclinical vascular disease and evaluate cardiovascular disease risk: a consensus statement from the American Society of Echocardiography Carotid IntimaMedia Thickness Task Force. Endorsed by the Society for Vascular Medicine. J Am Soc Echocardiogr. 2008; 21: 93-111.

17. Demer LL, Tintut Y. Vascular calcification: pathobiology of a multifaceted disease. Circulation 2008; 117: 2938-48. 